\title{
Teaching of the Integrated Management of Childhood Illness strategy in undergraduate nursing programs ${ }^{1}$
}

\author{
Elizabeth Fujimori² \\ Cinthia Hiroko Higuchi ${ }^{3}$ \\ Emília Gallindo Cursino ${ }^{4}$ \\ Maria De La Ó Ramallo Veríssimo ${ }^{5}$ \\ Ana Luiza Vilela Borges 5
}

\author{
Débora Falleiros de Mello ${ }^{6}$ \\ Lucila Castanheira Nascimento ${ }^{6}$ \\ Verónica Behn ${ }^{7}$ \\ Lynda Law Wilson ${ }^{8}$
}

Objective: To describe and analyze the teaching of the Integrated Management of Childhood Illness (IMCI) strategy on Brazilian undergraduate nursing programs. Method: Integrating an international multicentric study, a cross-sectional online survey was conducted between May and October 2010 with 571 undergraduate nursing programs in Brazil Results: Responses were received from 142 programs, 75\% private and 25\% public. 64\% of them included the IMCI strategy in the theoretical content, and $50 \%$ of the programs included IMCI as part of the students' practical experience. The locations most used for practical teaching were primary health care units. The 'treatment' module was taught by the fewest number of programs, and few programs had access to the IMCI instructional manuals. All programs used exams for evaluation, and private institutions were more likely to include class participation as part of the evaluation. Teaching staff in public institutions were more likely to have received training in teaching IMCI. Conclusion: In spite of the relevance of the IMCI strategy in care of the child, its content is not addressed in all undergraduate programs in Brazil, and many programs do not have access to the IMCI teaching manuals and have not provide training in IMCI to their teaching staff.

Descriptors: Integrated Management of Childhood Illness; Child Health (Public Health); Nursing; Education, Higher.

\footnotetext{
${ }^{1}$ Supported by Conselho Nacional de Pesquisa e Desenvolvimento Científico e Tecnológico (CNPq), process \# 479475/2010-5.

2 PhD, Associate Professor, Escola de Enfermagem, Universidade de São Paulo, São Paulo, SP, Brasil.

${ }^{3}$ Undergraduate Student in Nursing, Escola de Enfermagem, Universidade de São Paulo, São Paulo, SP, Brazil. Scholarship holder of the Programa Institucional de Bolsas de Iniciação Científica do Conselho Nacional de Desenvolvimento Científico e Tecnológico (PIBIC/CNPq).

${ }^{4}$ PhD, Adjunct Professor, Escola de Enfermagem, Universidade Federal Fluminense, Rio de Janeiro, RJ, Brazil.

${ }^{5}$ PhD, Professor, Escola de Enfermagem, Universidade de São Paulo, São Paulo, SP, Brasil.

${ }^{6}$ PhD, Associate Professor, Escola de Enfermagem de Ribeirão Preto, Universidade de São Paulo, WHO Collaborating Centre for Nursing Research Development, Ribeirão Preto, SP, Brasil.

7 MSc, Full Professor, Universidad de Concepción, Concepción, Chile.

${ }^{8} \mathrm{PhD}$, Professor, School of Nursing, University of Alabama, Birmingham, USA.
} 


\section{Introduction}

The Integrated Management of Childhood Illness (IMCI) strategy was proposed in the 1990's by the World Health Organization (WHO), the Pan American Health Organization (PAHO) and the United Nations Children's Fund (UNICEF), to address the alarming rates of childhood morbidity and mortality. The IMCI was officially introduced in Brazil in 1996(1).

The strategy consists of a set of criteria for assessing, classifying and treating the prevalent illnesses that can progress to become serious and kill children under five years old. The purpose of the IMCI is not to establish a diagnosis, but to systematically and integrally evaluate positive predictive clinical signs which define the need to initiate treatment in primary care or the home, or to refer appropriately to a unit providing higher level care. The program involves families, and includes a focus on integrating curative, preventative, and health promotion activities $^{(2)}$. The strategy reinforces the concept of integrality and strengthens the capacity for planning and resolution of problems at the primary level of care, making available the most appropriate tools for dealing with the illnesses prevalent in childhood(2).

Since 1998, the Brazilian Ministry of Health(3) has recommended inclusion of the IMCI strategy in the Medicine and Nursing curricula, in order to train professionals who are competent to care for the child in the context of primary care, the family, and the community(4).

Studies on the strategy's insertion in the teaching of pediatrics in medical schools have evidenced good acceptance on the part of the students and improvement in their knowledge of child health ${ }^{(5-8)}$. In the clinical field, improvement in the quality of care was observed, as an effect of the professionals' training in $\mathrm{IMCI}^{(9)}$. In spite of this, in the case of nursing, only $37 \%$ of the teaching staff of 140 schools in 16 countries in Latin America had been trained in the strategy ten years ago(10).

Recent publications have highlighted the importance of the development of global standards of education in nursing, in order to strengthen nursing education. Nursing programs must train culturally competent undergraduate students who understand the social determinants of health and who are trained to practice and to meet the population's health needs ${ }^{(11)}$.
However, the curricula in many nursing programs remain linked to the biomedical model, and many do not include concepts of critical thinking and current pedagogical practices due to inadequate preparation of faculty(12). The current literature addresses benefits of IMCI strategy for children and caregivers $^{(13)}$; however no recent publications were identified evaluating how IMCI strategy is taught to nursing students. The present study, therefore, contributes to the literature by examining the approaches used to teach IMCI strategy in schools of nursing in Brazil.

Due to the IMCI's importance in improving child health, the PAHO continues to encourage the governments of Latin-American countries to incorporate this strategy into their health programs and into curricula of health professional educational programs. In order to facilitate teaching IMCI in schools of nursing, PAHO produced a manual in Spanish for undergraduate nursing programs in 2009*. Simultaneously, it proposed to the Red Internacional de Enfermería en Salud Infantil (Red ENSI) (International Network of Nursing in Child Health) to evaluate the teaching of child health in nursing training, so as to identify the situation of the incorporation of the IMCI strategy into undergraduate nursing courses ${ }^{(14)}$ prior to the manual's release, so as to analyze its later effect. The Red ENSI brings together nursing researchers and nursing professionals from various countries** who are experts in the care and teaching of child's health. Red ENSI is also responsible for coordinating the multicentric study entitled "The teaching of care for illnesses prevalent in childhood in schools and colleges of Latin America and the Caribbean".

The present study reports findings from data collected for this larger multicentric study in Brazil. The general objective of the study was to describe and analyze the teaching of IMCI strategy in Brazilian undergraduate nursing programs.

\section{Methods}

This research has a quantitative and descriptive cross-sectional approach, and was approved by the Research Ethics Committee of the University of São Paulo Nursing School ( $\left.n^{\circ} 825 / 2009 / C E P-E E U S P\right)$ and by the Brazilian National Research Ethics Commission (Decision CONEP no 15531).

\footnotetext{
* http://www.bvsde.paho.org/texcom/AIEPI/AIEPIClinico.pdf

** Argentina, Bolivia, Brazil, Chile, Colombia, Costa Rica, Cuba, El Salvador, Equador, Spain, the United States, Guatemala, Honduras, Mexico, Nicaragua, Panama, Peru, Puerto Rico, Portugal, the Dominican Republic, Uruguay, Venezuela.
} 
The study population included all of the undergraduate nursing programs in Brazil. In 2009*, the Ministry of Education's website indicated the registration of 782 courses; however, the researchers were only able to obtain contact information for 571 of these programs. An email was sent to a contact in each of these programs, inviting them to participate in the research. All of the campuses belonging to the same institutions were considered, due to the possibility of the curricular matrix or the course programs differing.

The invitation included a brief explanation of the study's objective, and an access link to the SurveyMonkey server, which hosted the questionnaire. The addressee was requested to re-direct the message to the member of staff responsible for teaching child health. Participation was voluntary, confirmed through acceptance of the terms of free and informed consent, with confidentiality and the anonymity of the institution guaranteed.

The structured and self-administered instrument used for the data collection was initially constructed in Spanish, based on a review of the literature on the area and the experience of the Red ENSI members. It was translated into Portuguese by the authors and back-translated by a professional fluent in both Spanish and Brazilian Portuguese, who was unfamiliar with the original document and the details of the research. After the comparison between the two versions and final consensus on the Brazilian version, the instrument was converted into a questionnaire for the participants to access online using the SurveyMonkey website**. The instrument included questions regarding demographic data, information about the academic program, and information about teaching nursing care for children under age five. Respondents were also asked to provide information about the incorporation of IMCI strategy in their nursing undergraduate programs and resources available for teaching it; and space for comments and clarifications concerning filling out the instrument.

Data collection took place between May and October 2010. Messages with reminders about the research were sent out every 15 days, over a period of 45 days. Of the total, 253 institutions started the process of filling out the questionnaire, and 142 finished (24.9\% of the total).

The data were abstracted from SurveyMonkey, recorded onto an Excel spreadsheet, and analyzed using the software Statistical Package for Social Sciences (SPSS ${ }^{\circledR}$ version 15.0). For the descriptive analysis, frequency tables were constructed using absolute numbers, proportions, minimum and maximum values, averages and standard deviation. Public institutions were compared with private, which included "philanthropic", "mixed", and "others", using Fisher's exact test for the categorical variables, and the t test for continuous variables, both with a $5 \%$ level of significance.

\section{Results}

Table 1 presents information about the total number of institutions contacted by region ( $\mathrm{N}$ ) and the number of institutions which responded ( $n$ ). Proportionately, there was greater participation from institutions in the Southern region, followed by the Southeast and CentralWest regions. Over three-quarters of the responding institutions were private, the majority conferred the title of Bachelor in Nursing (69.0\%) and had programs with over 4000 hours $(55.6 \%)$

Table 1 - Distribution of the number of undergraduate nursing courses contacted, and responses obtained by region. Brazil, 2010

\begin{tabular}{lccc}
\hline \multirow{2}{*}{ Regions of Brazil } & \multicolumn{3}{c}{ Undergraduate nursing courses } \\
\cline { 2 - 4 } & $\mathbf{N}$ & $\mathbf{n}$ & $\%$ \\
\hline South & 101 & 37 & 36.6 \\
Southeast & 251 & 63 & 25.1 \\
Center-West & 64 & 16 & 25.0 \\
Northeast & 122 & 24 & 19.7 \\
North & 33 & 2 & 6.0 \\
Total & 571 & 142 & 100.0 \\
\hline
\end{tabular}

Tables 2 and 4 present the results obtained compared to type of institution - private or public - with the total of institutions which responded $(\mathrm{N})$, and the responses obtained for each item $(n)$. The theoretical content of the IMCI was incorporated into the curricula of $64.1 \%$ of the courses, there being no statistical difference between public and private institutions. Equally, there was no difference in relation to the teaching strategies used, in which theoretical lessons predominated $(100.0 \%)$, followed by case studies (97.0\%). As an evaluative strategy, all used theoretical tests, but there was a difference concerning participation in theoretical lessons, which were considered more important in private institutions (Table 2 ).

* http://emec.mec.gov.br

** http:// www.surveymonkey.com 
Table 2 - Characterization of the theoretical teaching of IMCI regarding teaching and evaluative strategies, in public and private institutions. Brazil, 2010

\begin{tabular}{|c|c|c|c|c|c|c|c|c|c|}
\hline \multirow{2}{*}{ Theory teaching } & \multicolumn{3}{|c|}{ Public institutions } & \multicolumn{3}{|c|}{ Private institutions } & \multicolumn{3}{|c|}{ Total } \\
\hline & $\mathrm{N}$ & $\mathrm{n}$ & $\%$ & $\mathrm{~N}$ & $\mathrm{n}$ & $\%$ & $\mathrm{~N}$ & $\mathrm{n}$ & $\%$ \\
\hline Incorporation of IMCI & 33 & 23 & 69.7 & 98 & 61 & 62.2 & 131 & 84 & 64.1 \\
\hline \multicolumn{10}{|l|}{ Teaching strategy } \\
\hline Theory lessons & 22 & 22 & 100.0 & 60 & 60 & 100.0 & 82 & 82 & 100.0 \\
\hline Case studies & 17 & 16 & 94.1 & 53 & 52 & 98.1 & 70 & 68 & 97.1 \\
\hline Bibliographic research & 16 & 14 & 87.5 & 47 & 39 & 83.0 & 63 & 53 & 84.1 \\
\hline Group study & 14 & 11 & 78.6 & 52 & 44 & 84.6 & 66 & 55 & 83.3 \\
\hline Individual study & 14 & 11 & 78.6 & 44 & 36 & 81.8 & 58 & 47 & 81.0 \\
\hline Seminars & 11 & 7 & 63.6 & 46 & 35 & 76.1 & 57 & 42 & 73.7 \\
\hline Videos & 14 & 10 & 71.4 & 48 & 33 & 68.8 & 62 & 43 & 69.4 \\
\hline \multicolumn{10}{|l|}{ Evaluative strategies } \\
\hline Theory tests & 19 & 19 & 100.0 & 54 & 54 & 100.0 & 73 & 73 & 100.0 \\
\hline Participation in theory lessons* & 17 & 14 & 82.4 & 55 & 55 & 100.0 & 72 & 69 & 95.8 \\
\hline Case studies & 18 & 16 & 88.9 & 56 & 53 & 94.6 & 74 & 69 & 93.2 \\
\hline Group study & 15 & 11 & 73.3 & 51 & 47 & 92.2 & 66 & 58 & 87.9 \\
\hline Individual work & 11 & 9 & 81.8 & 48 & 38 & 79.2 & 59 & 47 & 79.7 \\
\hline
\end{tabular}

$* \mathrm{p}<0.05$ (Fisher's exact test)

The characteristics of the practical teaching of IMCI are presented in Table 3. This occurred in only half of the courses studied, without a statistical difference between the institutions, except regarding the classification of the health problems of the child, which was touched on more by the private institutions. Actions for general assessment of the child, questions for the carer about the child's health, guidance about general care and guidance about treatment were referred to equally. The carrying-out of treatment was the activity referred to least. The primary healthcare units were most used for the practical teaching, followed by hospitals and day cares and kindergartens, these last being used most by the private institutions. Interaction in the practice and participation was mentioned as an evaluative strategy (Table 3).

Table 3 - Characterization of the practical teaching of IMCI regarding occurrence, activities carried out, places teaching took place and evaluative strategies, in the public and private institutions. Brazil, 2010

\begin{tabular}{|c|c|c|c|c|c|c|c|c|c|}
\hline \multirow{2}{*}{ Practical teaching } & \multicolumn{3}{|c|}{ Public institutions } & \multicolumn{3}{|c|}{ Private institutions } & \multicolumn{3}{|c|}{ Total } \\
\hline & $\mathbf{N}$ & $\mathbf{n}$ & $\%$ & $\mathbf{N}$ & $\mathbf{n}$ & $\%$ & $\mathbf{N}$ & $\mathbf{n}$ & $\%$ \\
\hline Incorporation of IMCI & 32 & 18 & 56.3 & 93 & 45 & 48.4 & 125 & 63 & 50.4 \\
\hline \multicolumn{10}{|l|}{ Practical activities } \\
\hline General evaluation & 18 & 18 & 100.0 & 44 & 44 & 100.0 & 62 & 62 & 100.0 \\
\hline Questions to carer & 18 & 18 & 100.0 & 44 & 44 & 100.0 & 62 & 62 & 100.0 \\
\hline Guidance on general care & 17 & 17 & 100.0 & 44 & 44 & 100.0 & 61 & 61 & 100.0 \\
\hline Guidance as to treatment & 17 & 17 & 100.0 & 42 & 41 & 97.6 & 59 & 58 & 98.3 \\
\hline Classification of the problems* & 17 & 14 & 82.4 & 44 & 44 & 100.0 & 61 & 58 & 95.1 \\
\hline Determination of treatment & 17 & 15 & 88.2 & 41 & 30 & 73.2 & 58 & 45 & 77.6 \\
\hline Carrying out of treatment & 16 & 9 & 56.3 & 40 & 29 & 72.5 & 56 & 38 & 67.9 \\
\hline \multicolumn{10}{|l|}{ Places of teaching } \\
\hline Family Health Units & 16 & 16 & 100.0 & 43 & 39 & 90.7 & 59 & 55 & 93.2 \\
\hline Primary Care Units & 16 & 15 & 93.8 & 39 & 36 & 92.3 & 55 & 51 & 92.7 \\
\hline Hospitals & 11 & 9 & 81.8 & 37 & 35 & 94.6 & 49 & 40 & 81.6 \\
\hline Day cares or kindergartens* & 12 & 7 & 58.3 & 37 & 33 & 89.2 & 49 & 40 & 81.6 \\
\hline People's homes & 12 & 10 & 83.3 & 36 & 27 & 75.0 & 48 & 37 & 77.1 \\
\hline Outpatient centers & 12 & 8 & 66.7 & 31 & 20 & 64.5 & 43 & 28 & 65.1 \\
\hline Centers of excellence & 8 & 3 & 37.5 & 30 & 20 & 66.7 & 38 & 23 & 60.5 \\
\hline Emergency Room & 11 & 5 & 45.5 & 28 & 15 & 53.6 & 39 & 20 & 51.3 \\
\hline Community centers & 8 & 2 & 25.0 & 30 & 17 & 56.7 & 38 & 19 & 50.0 \\
\hline
\end{tabular}


Table 3 - (continuation)

\begin{tabular}{|c|c|c|c|c|c|c|c|c|c|}
\hline \multirow{2}{*}{ Practical teaching } & \multicolumn{3}{|c|}{ Public institutions } & \multicolumn{3}{|c|}{ Private institutions } & \multicolumn{3}{|c|}{ Total } \\
\hline & $\mathbf{N}$ & $\mathbf{n}$ & $\%$ & $\mathbf{N}$ & $\mathbf{n}$ & $\%$ & $\mathbf{N}$ & $\mathbf{n}$ & $\%$ \\
\hline \multicolumn{10}{|l|}{ Evaluative strategies } \\
\hline $\begin{array}{l}\text { Participation in practical } \\
\text { activities }\end{array}$ & 18 & 17 & 94.4 & 54 & 50 & 92.6 & 72 & 67 & 93.1 \\
\hline $\begin{array}{l}\text { Interaction of students in the } \\
\text { practice }\end{array}$ & 15 & 15 & 100.0 & 53 & 47 & 88.7 & 68 & 62 & 91.2 \\
\hline
\end{tabular}

The course workload dedicated to the theoretical teaching of IMCI varied from 2 hrs to 90 hrs, with an average of 24.9 hrs. For practical teaching, it varied from 4 hrs to 335 hrs, with an average of 42 hrs. The minimum and maximum variations were wide and did not differ between the public and private institutions.

It may be observed in Table 4 that only $39.4 \%$ of the institutions had teaching staff who were trained in
IMCI strategy, with a statistically-significant difference between the public and private institutions. A small number of courses had an instructor who was trained for the practical teaching (14.3\%) and few had manuals for teaching IMCI available for students in the libraries (28.7\%). Almost all showed interest in receiving the Clinical Manual for teaching the IMCI strategy in nursing.

Table 4 - Characterization of the resources available for teaching of IMCI in the public and private institutions. Brazil, 2010

\begin{tabular}{|c|c|c|c|c|c|c|c|c|c|}
\hline \multirow{2}{*}{ Characterization of the resources } & \multicolumn{3}{|c|}{ Public institutions } & \multicolumn{3}{|c|}{ Private institutions } & \multicolumn{3}{|c|}{ Total } \\
\hline & $\mathbf{N}$ & $\mathbf{n}$ & $\%$ & $\mathbf{N}$ & $\mathbf{n}$ & $\%$ & $\mathbf{N}$ & $\mathbf{n}$ & $\%$ \\
\hline Having a trained lecturer ${ }^{\star}$ & 33 & 21 & 63.6 & 104 & 33 & 31.7 & 137 & 54 & 39.4 \\
\hline Trained instructor (field) & 32 & 4 & 12.5 & 101 & 15 & 14.8 & 133 & 19 & 14.3 \\
\hline Having an $\mathrm{IMCl}$ manual in the libraries & 31 & 8 & 25.8 & 98 & 29 & 29.6 & 129 & 37 & 28.7 \\
\hline Lecturer researching child health & 33 & 15 & 45.4 & 104 & 39 & 35.7 & 137 & 54 & 39.4 \\
\hline Interest in the manual & 32 & 32 & 100.0 & 105 & 103 & 98.0 & 137 & 135 & 98.5 \\
\hline
\end{tabular}

\section{Discussion}

Research that uses the Internet for data collection compares with those that use the post, in that the response rate is similar to that obtained using the post. It has been said that virtual research has a response rate which varies from 15 to $29 \%{ }^{(15)}$. Thus, the response rate obtained in the present study (25\%), despite appearing low, represents the percentage which was expected. However, when one considers that the Internet offers a form of data collection which is not limited by time, cost or distance, the low number of responses does constitute a limitation, and one should interpret the results with caution.

The IMCI strategy is fundamental to training nursing students, mainly because it integrates practical and technical-scientific knowledge to promote child health in health services, homes, and communities ${ }^{(16)}$, improving their abilities to communicate with caregivers ${ }^{(13)}$. In this study, however, the incorporation of IMCI theoretical teaching was observed in only two-thirds of the undergraduate programs included in the sample, in spite of its potential and recommendation by the Brazilian Ministry of Health.

It was observed that traditional teaching methods - such as lectures - predominate across all the courses. The use of case studies, on the other hand, was also much cited, this being a more active method, as it makes it possible to place the students before a situation which is similar to reality, in which they can carry out a diagnostic analysis of the problem, seek information for referring the problem situation, apply the necessary knowledge and integrate theory and practice; this prepares them to face complex and contextualized situations ${ }^{(17)}$.

The methodology proposed in the IMCI strategy entails problematization, as it proposes that based on the identification of clinical signs, the theory readings which explain the technical reasons for incorporating a particular sign in the definition of the clinical picture are deepened, moving from situations of lower to greater complexity ${ }^{(18)}$. 
The use of video was the least-used strategy in the teaching of IMCI, although, according to nursing(19) and

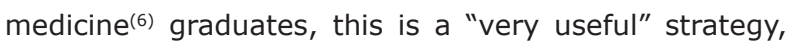
which should be kept on as a pedagogical resource, as it helps to consolidate the learning, and favors the application of the knowledge in professional practice.

It should be highlighted that the practical activities for teaching IMCI were present only in half of the courses studied - which weakens the learning in the case of the courses which include only theoretical activities. Regarding the actions undertaken in practice, the results obtained repeated those of a previous study of nursing graduates, in which approximately half had used the "treating the child" module "rarely or never"(20). The fact that this content was little-addressed in the training may contribute to the difficulties which the health professionals reported in applying the treatment module in their practice, due to clear restrictions on the prescription of medications by nurses, as well as the weak insertion of the strategy in the health services(19). It might leads to a circle in which the health professional, little prepared to perform the action, does not feel able to do it, in the face of the restrictions she/he meets in the world of work.

Given the IMCI's basis in primary care, the Family Health Units and the Primary Care Centers were the placement areas most referred to for the strategy's practical teaching. Thus, its initial implantation occurred prioritarily in the municipalities which had the Family Health Strategy and the Community Health Workers Program ${ }^{(1)}$. Indeed, the incorporation of the IMCI into primary care is fundamental to fostering its effective inclusion in the nursing and medicine undergraduate courses, this being these professionals' training setting. The study, however did not specify whether the units where the students carried out their practical learning had adopted the IMCI strategy, and one should bear in mind that the failure of the majority of public primary care institutions to use the IMCI is an important obstacle to the genuine incorporation of the strategy into care for the child in primary care ${ }^{(18)}$.

The hospital itself was also a teaching/learning field used significantly in the undergraduate nursing courses investigated, with the percentage found being similar to that found in nursing schools and colleges elsewhere in Latin America(10). The hospital is a useful resource because it concentrates a large number of children with serious signs of the prevalent illnesses, and offers the students the opportunity to reflect on primary care's ability to resolve the health issues.
Learning about the IMCI strategy involves not only the student's ability to memorize - which is assessed in theory tests, as mentioned by the majority of courses but also in his or her ability to understand and use what was learnt in situations in practice. For this reason, the methodology must evaluate the students' acquisition of motor, interpersonal and intellectual skills as much as their acquisition of knowledge. This may be being taken into account, as there were reports of other evaluation strategies $^{(17)}$.

The average total of trained lecturers (39.4\%) deserves to be emphasized. As this is practically the same rate $(37 \%)$ ascertained in the period 2001$2002^{(10)}$, there had been no advance in the training of lecturers in nearly a decade, a situation which influences the decision to include or not the content of the IMCI strategy in the nursing curriculum, and which may compromise both the quality of the teaching and the incorporation of the strategy into professional practice.

It is also important to consider the statistical difference of lecturers trained in the strategy: a higher proportion of trained lecturers in the public institutions might support greater incorporation of the IMCI in teaching of theory and practice, but it was not observed in this study.

There are considerations about the initial resistance to the incorporation of the IMCI in the curriculums on the part of nursing and medicine lecturers, as these consider the strategy to be simplistic and prejudicial against diagnostic technology ${ }^{(18)}$. With the creation of the National Centers of Excellence in Child Health (CRNS-Child) by the Brazilian Ministry of Health, which incentivized the training of lecturers and strengthened the importance of training the students during their undergraduate courses, changes were observed in some institutions, with more teaching of the issue and more understanding of the theoretical complexity which the IMCI strategy is based on ${ }^{(18)}$, indicating that its continuity may influence this scenario.

The low number of nursing instructors who are trained in this field, as well as hindering the teaching process, may explain the failure to use the IMCI in care for the health of the child. Ignorance of the strategy on the part of health professionals, which results in the failure to support colleagues who want to adopt it in their work, has been identified as an important barrier to the effective implementation of the $\operatorname{IMCI}^{(19,21)}$.

According to the Ministry of Health(3), in 2002, all the states in Brazil already had IMCI-qualified professionals to teach it for health student and health 
professionals. One year later, however, there had been a significant reduction in IMCI training, in parallel with the redefinition of the Brazilian Ministry of Health's priorities $^{(22)}$. The strategy has therefore passed through difficulties regarding the process of training health professionals and lecturers.

Generally speaking, in the majority of cases, the training takes place in theory-practice on-site courses with high course-loads, which makes it difficult for health professionals to participate, besides the high cost for the institutions. In Peru, since 2008, the IMCI strategy has gained a virtual space through the clinical course's adaptation for, and incorporation into, the ICATT (IMCI Computerized Adaptation and Training Tool) software ${ }^{(23)}$. Training through the use of this software showed that the use of this tool, in addition to training a higher number of participants, reduced the cost of the training by $50 \%{ }^{(24)}$, which was also verified in Kenya and Uganda ${ }^{(25)}$, indicating alternatives for increasing the number of lecturers and health professionals trained in Brazil.

Another aspect related to the failure to incorporate teaching of IMCI into the undergraduate courses is the inadequacy of instructional material, as verified in the present study. Although the Brazilian Ministry of Health has made the material available online, not all the students have computers to access the material. In addition to this, another barrier to the teaching of the IMCI strategy during the undergraduate course is the format of the material, which is prepared for health professionals rather than students ${ }^{(18)}$. Thus, one can see the importance of and need for a Portuguese-language version of the "Clinical Manual for teaching the IMCI in Nursing", currently available only in Spanish.

This is justified by the high percentage of responses indicating interest in receiving the Clinical Manual, especially intended for the teaching of the IMCI in nursing schools. There can be no doubt that the translation to Portuguese, along with its widespread use, would be a big step forward in the incorporation of the IMCI in undergraduate nursing courses in Brazil, with a view to training health professionals to work using the care model called for by the strategy, and to act with efficient practices in primary care directed at child's health.

We analyzed relevant points in the IMCI strategy teaching. We also highlighted gaps in teaching strategies that should be overcome to improve undergraduate nursing students learning process. Future research is needed to investigate those aspects about IMCI teaching in child health care.

\section{Conclusions}

This investigation of the teaching of the IMCI strategy showed that its theoretical content is included in two-thirds of undergraduate nursing courses, with practical teaching found in only half of the Brazilian courses investigated. Generally speaking, there is no difference between the course load, teaching strategies or evaluation of the teaching of the IMCI in public and private institutions, although the number of teaching staff trained in it is lower in the private institutions, which may entail a weakening of the quality of the teaching. The interest in receiving the Clinical Manual for Teaching Nursing on the strategy evidences the lack of appropriate teaching material for undergraduate teaching, indicating that its translation could contribute significantly to its being inserted into, and adhered to more, in the initial training of the nurse.

\section{Acknowledgments}

To Natália de Castro Nascimento and Renata Luciria Monteiro for their contribution in data collection.

\section{References}

1. Felisberto E, Carvalho EF, Samico I. Estratégia Atenção Integrada às Doenças Prevalentes na Infância (AIDPI): Considerações sobre o processo de implantação. Revista IMIP 2000;14(1):24-31.

2. Benguigui Y. Integrated Management of Childhood Illness (IMCI): An innovative vision for child health care. Rev Bras Saúde Mater Infant. 2001;1(3):223-36.

3. Ministério da Saúde (BR). AIDPI. Atenção Integrada às Doenças Prevalentes na Infância: curso de capacitação: introdução - módulo 1. Ministério da Saúde, Organização Mundial da Saúde, Organização Pan-Americana da Saúde. 2. ed. rev., 1.a reimpressão. Brasília (DF): Ministério da Saúde; 2003. 32 p. (Série F. Comunicação e Educação em Saúde)

4. Cunha JLA, Silva MAFS, Amaral JF. A estratégia de "Atenção Integrada às Doenças Prevalentes na Infância - AIDPI" e sua implantação no Brasil. Rev Pediatr Ceará 2001;2(1):33-8.

5. Bringel GM, Oliveira AFC. Atenção Integrada as Doenças Prevalentes da Infância (AIDPI) no Ensino de Pediatria. Rev bras Ciências Saúde 2002;6(3):291-8.

6. Paixão AC, Barreto ES, Amaral JJF. Atenção Integrada às Doenças Prevalentes na Infância (AIDPI) e o ensino da pediatria na Universidade Federal de Sergipe. Rev Pediatr Ceará 2003;4(1):51-4. 
7. Souza ELS, Barreto MRR, Nunes GR, Carvalho IFS, Souza SLF. Avaliação de alunos de graduação em Medicina após treinamento na estratégia AIDPI. Rev Ciênc Méd Biol. 2005;4(1):7-14.

8. Abdelrahman $\mathrm{SH}$, Alfadil SM. Introducing the IMCI community component into the curriculum of the faculty of medicine of the University of Gezira. East Mediterr health j. 2008;14(3):731-41.

9. Amaral J, Gouws E, Bryce J, Leite AJM, Cunha ALA, Victora CG. Effect of Integrated Management of Childhood Illness (IMCI) on health worker performance in Northeast-Brazil. Cad Saúde Pública 2004;20(Suppl 2):209-19.

10. Benguigui $Y$, Malvarez S, Obregón R. La enseñanza de la salud infantil en las escuelas $y$ facultades de enfermería de América Latina. Washington (DC): Pan American Health Organization; 2005.

11. Wilson LL. Capacitando enfermeiros para o cuidado em saúde global. Rev Latino-Am. Enfermagem $2011 ; 19(6): 1-2$.

12. Almeida $A H$, Soares $C B$. Educação em saúde: análise do ensino na graduação em enfermagem. Rev. LatinoAm. Enfermagem 2011;19(3):614-21.

13. Paranhos VD, Pina JC, Mello DF. Integrated management of childhood illness with the focus on caregivers: an integrative literature review. Rev LatinoAm. Enfermagem 2011;19(1):203-11.

14. Harrison L, Montenegro G, Malvarez S, Astudillo M, Behn V, Bertolozzi MR, et al. The network for nursing in child health. Pediatr Nurs. 2008;34(2):113-6.

15. Comley P. Pop-up surveys: what works, what doesn't work and what will work in the future. Net Effects [internet]. 2000 [acesso em: 06 nov 2012];3. Disponível em: http://www.websm.org/db/12/813/rec/ 16. Veríssimo MLOR, Mello DF, Bertolozzi MR, Chiesa AM, Sigaud CHS, Fujimori E, et al. A formação do enfermeiro e a estratégia atenção integrada às doenças prevalentes na infância. Rev Bras Enferm. 2003;56(4):396-400.

17. Masetto MT. Competência pedagógica do professor universitário. São Paulo: Summus; 2003. 48 p.

18. Cabral IE, Rodrigues EC. O ensino da AIDPI na enfermagem. In: Cunha ALAS, Benguigui Y, Silva MASF. Atenção Integrada às Doenças Prevalentes na Infância. implantação e avaliação no Brasil. Rio de Janeiro: Fiocruz; 2006. p. 187-203.

19. Higuchi $\mathrm{CH}$, Fujimori $\mathrm{E}$, Cursino EG, Chiesa $\mathrm{AM}$, Veríssimo MLÓR, Mello DF. Atenção Integrada às Doenças Prevalentes na Infância (AIDPI) na prática de enfermeiros egressos da USP. Rev. Gaúcha Enferm. 2011;32(2):241-7.

20. Fujimori $\mathrm{E}$, Higuchi $\mathrm{CH}$, Carneiro TAB, Borges ALV, Chiesa AM, Veríssimo MLÓR, et al. Integrated Management of Childhood Illness (IMCI): Knowledge and practice of nurses who have graduated from school of nursing at University of São Paulo-a case study. Online braz j nurs. [internet]. 2010 [acesso: 12 mai 2010];9(1). Disponível em: http://www.objnursing.uff.br/index.php/ nursing/article/view/j.1676-4285.2010.2657/589

21. Horwood C, Voce A, Vermaak K, Rollins N, Qazi S. Experiences of training and implementation of integrated management of childhood illness-IMCI in South Africa: a qualitative evaluation of the IMCI case management training course. BMC Pediatr. [internet] 2009. [acesso em: 27 jul 2010]; 9:62. Disponível em: http://www. biomedcentral.com/1471-2431/9/62

22. Amorim DG, Adam T, Amaral JJF, Gouws E, Bryce J, Victora CG. Integrated Management of Childhood Illness efficiency of primary health in Northeast Brazil. Rev Saúde Públ. 2008;42(2):183-90.

23. Huamán D, Dávila M. La estrategia AIEPI se consolida en el Perú: AIEPI Perú lo más buscado y visitado en el sitio Web de la OPS/OMS Perú. PAHO Bulletins [internet] 2011. [acesso: 25 jan 2012];20(7). Disponivel em: http://new.paho.org/bulletins/index.php?option=com content\&task $=$ view\&id $=986 \&$ Itemid $=308$

24. Durand CU. La Enseñanza Aprendizaje de AIEPI Clínico con la herramienta AIEPI ICATT (IMCI Computerized and Training Tool) en la Región Junín, Perú 2010. PAHO Bulletins [internet]. 2011 [acesso: 25 jan 2012];20(5). Disponível em: http://new.paho.org/ bulletins/index.php?option $=$ com_content\&task $=$ view\&i $\mathrm{d}=988$ \&Itemid $=308$

25. Sotomayor CP. AIEPI y el uso de las TICs: Mejorando los conocimientos del personal de salud en AIEPI clínico, a través del uso del software ICATT y las TICs, en establecimientos de salud de la Región Ucayali, Perú. PAHO Bulletins [internet]. 2011 [acesso: 25 jan 2012]; 20(3). Disponível em: http://new.paho.org/bulletins/ index.php?option $=$ 